\title{
Transgenerational plasticity and antiviral immunity in the Pacific oyster (Crassostrea gigas) against Ostreid herpesvirus 1 (OsHV-1)
}

\author{
Lafont Maxime ${ }^{1,2}$, Goncalves Patricia ${ }^{1,3}$, Guo Ximing ${ }_{1,3}^{4}$, Montagnani Caroline ${ }^{2}$, Raftos David ${ }^{1,3}$, \\ Green Timothy ${ }^{1,3, *}$
}

${ }^{1}$ Sydney Institute of Marine Science, Chowder Bay, Sydney, Australia

2 IHPE, Université de Montpellier, CNRS, Ifremer, Université de Perpignan Via Domitia, France

${ }^{3}$ Macquarie University, Department of Biological Sciences, Sydney, Australia

${ }^{4}$ Haskin Shellfish Research Laboratory, Rutgers University, Port Norris, NJ, USA

* Corresponding author : Timothy Green, email address : timothy.green@viu.ca

\begin{abstract}
:
The oyster's immune system is capable of adapting upon exposure to a pathogen-associated molecular pattern (PAMP) to have an enhanced secondary response against the same type of pathogen. This has been demonstrated using poly $(\mathrm{I}: \mathrm{C}$ ) to elicit an antiviral response in the Pacific oyster (Crassostrea gigas) against Ostreid herpesvirus (OsHV-1). Improved survival following exposure to poly $(\mathrm{l}: \mathrm{C})$ has been found in later life stages (within-generational immune priming) and in the next generation (transgenerational immune priming). The mechanism that the oyster uses to transfer immunity to the next generation is unknown. Here we show that oyster larvae have higher survival to OsHV-1 when their mothers, but not their fathers, are exposed to poly $(\mathrm{l}: \mathrm{C})$ prior to spawning. RNA-seq provided no evidence to suggest that parental exposure to poly $(\mathrm{l}: \mathrm{C})$ reconfigures antiviral gene expression in unchallenged larvae. We conclude that the improved survival of larvae might occur via maternal provisioning of antiviral compounds in the eggs.
\end{abstract}

\section{Highlights}

- The molecular mechanism involved in transgenerational immune priming was investigated in the oyster, Crassostrea gigas. Crassostrea gigas larvae have higher survival to OsHV-1 when their mothers, but not their fathers, are exposed to poly(l:C) prior to spawning. RNA-seq provided no evidence to suggest that parental exposure to poly(l:C) reconfigures antiviral gene expression in unchallenged larvae. Improved survival of $C$. gigas larvae might occur via maternal provisioning of antiviral compounds in the eggs.

Keywords : Crassostrea gigas, OsHV-1, transgenerational immune priming, Trained immunity, RNA-seq 


\section{Introduction}

Invertebrates can mount sophisticated immune responses with the potential to exhibit a form of innate immune memory (Chang et al., 2018; Contreras-Garduno et al., 2016; Milutinovic and Kurtz, 2016). After exposure to certain stimuli or parasite infections, the immune system of some invertebrate species can be primed to respond more vigorously upon a secondary infection caused by the same type of parasite (Contreras-Garduno et al., 2016). This longlasting, group-specific immune response in invertebrates is called 'immune-priming' (Kurtz and Franz, 2003). In some incidences, immune priming occurs not only within a generation, but also across generations with offspring from primed parents also having improved survival to parasite exposure, a state called 'transgenerational immune-priming' (Little et al., 2003; Sadd et al., 2005). Immune priming has been reported in different groups of invertebrates, including ctenophores, sponges, mollusks and arthropods (Milutinovic and Kurtz, 2016). Studies investigating the phenomenon of immune-priming in invertebrates are quite heterogeneous and largely differ in terms of host-parasite combination, experimental design, elicitors used for priming (i.e. non-lethal dose of parasite or PAMP) and route of priming (i.e. oral or injection) (reviewed by Contreras-Garduno et al., 2016). This heterogeneous array of experiments makes it complicated to provide a mechanistic explanation for this phenomenon.

Ostreid herpesvirus 1 (OsHV-1) is responsible for serious economic losses of the edible Pacific oyster, Crassostrea gigas (Burge et al., 2006; Jenkins et al., 2013; Keeling et al., 2014; Renault et al., 1994; Segarra et al., 2010). OsHV-1 can cause $100 \%$ mortality rate of $C$. gigas in less than one week (Paul-Pont et al., 2014), with the commercial production of C. gigas having now ceased entirely in several affected estuaries within Australia (Whittington et al., 2015). Urgency to mitigate the impacts of OsHV-1 has led to a closer examination of the antiviral responses of $C$. gigas to OsHV-1 infection (reviewed by Green and Speck, 2018). Observational studies suggest $C$. gigas are capable of adapting to OsHV-1 infection. $C$. gigas that have survived a mortality event appeared to be more resistant later in life to OsHV-1 (Evans et al., 2017; Pernet et al., 2012) and female C. gigas infected with OsHV-1 can transfer this protection to their offspring (Barbosa-Solomieu et al., 2005).

Experimental studies using a heterologous immune-priming model provide evidence of immune plasticity in C. gigas to OsHV-1 infection (Green and Montagnani, 2013; Green et al., 2015b; Lafont et al., 2017; Pauletto et al., 2017). The immune system of $C$. gigas can be primed with synthetic virus-associated molecular patterns (i.e. poly(I:C)) to induce an antiviral response that hampers subsequent infection with OsHV-1 (Green and Montagnani, 2013; Green et al., 2014b). This protection to OsHV-1 can be long-lasting, persisting for at 
least 5 months (Lafont et al., 2017). Furthermore, this protection appears to be transmitted to offspring. C. gigas larvae produced from parents stimulated with poly(I:C) have improved survival to OsHV-1 infection (Green et al., 2016). Discovering the mechanism used by $C$. gigas to transmit antiviral immunity to the next generation would be highly beneficial to the aquaculture industry. This knowledge could motivate the development of practical and costeffective treatments for improving oyster health (Contreras-Garduno et al., 2016; Wang et al., 2015).

Transgenerational immune priming in invertebrates can arise from both maternal and paternal sources (McNamara et al., 2014; Roth et al., 2010; Zanchi et al., 2011). Maternal immune priming appears to be mediated by at least three non-exclusive mechanisms. Mothers exposed to pathogens or certain stimuli may provision their eggs with antimicrobial compounds (Yue et al., 2013). This antimicrobial activity declines as the antimicrobial compounds are metabolized in the developing embryos (Benkendorff et al., 2001). Mothers may also transmit signals to enhance the immune response of their offspring (Barribeau et al., 2016; Hernandez Lopez et al., 2014; Zanchi et al., 2011). These signals include the transfer of microbial degradation products (i.e. PAMPs) to their developing embryos to prime their immune response (Freitak et al., 2014), or via epigenetic mechanisms, such as DNA chromatin modification or small RNA, to elevate the constitutive expression of immune effector genes (Castro-Vargas et al., 2017; Norouzitallab et al., 2016). Paternal immune priming can also be transmitted by epigenetic mechanisms via the sperm or by compounds transferred with the seminal fluid (Eggert et al., 2014).

Here, we investigated the mechanisms that underpin transgenerational immune priming in C. gigas against OsHV-1, using the immune elicitor poly(I:C). This study aimed to (i) investigate the effect of time between parental exposure to poly(I:C) and spawning on the resistance of larvae to OsHV-1 infection, (ii) quantify the contribution of maternal and paternal provisioning to offspring response, and (iii) determine if parental exposure to poly(I:C) reconfigures the constitutive expression of immune-related genes in unchallenged C. gigas larvae.

\section{Materials and Methods}

\subsection{Oysters, Immune Challenge \& Mating Trials}

Adult Crassostrea gigas were collected from Port Stephens estuary (NSW, Australia) and held in conditioning tanks at the Sydney Institute of Marine Science (Sydney, Australia). OsHV-1 DNA has not been detected in C. gigas cultivated in Port Stephens estuary (Go et 
al., 2017). Adult $C$. gigas were held in $60 \mathrm{~L}$ tanks at $21^{\circ} \mathrm{C}$ with supplemental feeding with live microalgae (Isochrysis galbana, Chaetoceros muelleri) and microalgae concentrate (Shellfish Diet 1800, Reed Mariculture). Prior to spawning, C. gigas had a notch filed in their

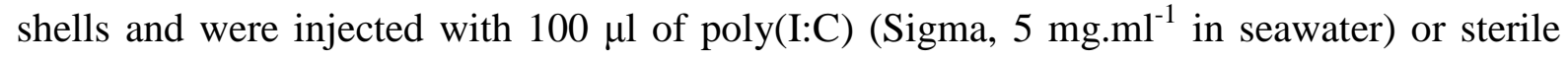
seawater (control) in the adductor muscle. C. gigas were stripped spawned by making small incisions in the gonad with a scalpel blade, and washing gametes into a plastic beaker with 1 $\mu \mathrm{m}$ filtered seawater. Gametes from each parent were kept separate until fertilization. Fertilization strategies are outlined below. Fertilized eggs were transferred to individual $20 \mathrm{~L}$ tanks filled with $5 \mu \mathrm{m}$ filtered seawater (temperature $21^{\circ} \mathrm{C}$, salinity $35 \mathrm{ppt}$ ) and D-veliger

113 larvae were harvested at $24 \mathrm{~h}$ post-fertilization by draining tanks through a $40 \mu \mathrm{m}$ nylon 114 sieve.

Experimental infection of $C$. gigas D-larvae with OsHV-1 was conducted according to the protocol outlined in Burge and Friedman (2012). Experiments involving OsHV-1 were conducted in a physical containment level 2 (PC2) facility at the Sydney Institute of Marine and all waste arising from experiments was decontaminated by heat sterilization (autoclaved at $121{ }^{\circ} \mathrm{C}$ for $15 \mathrm{~min}$ (Hick et al., 2016). Briefly, gill and mantle tissue from OsHV-1 infected and non-infected adult $C$. gigas was homogenized in 10-volumes of sterile seawater containing 1000 units. $\mathrm{ml}^{-1}$ of penicillin and $1 \mathrm{mg} \cdot \mathrm{ml}^{-1}$ of streptomycin, clarified by centrifugation and $0.2 \mu \mathrm{m}$ filtered to prepare OsHV-1 and control homogenates, respectively (Burge and Friedman, 2012; Renault et al., 2011). D-veliger larvae (24 h post-fertilization) from each family were placed in duplicate $500 \mathrm{ml}$ Erlenmeyer flasks containing $200 \mathrm{ml}$ of sterile seawater, 100 units. $\mathrm{ml}^{-1}$ of penicillin and $0.1 \mathrm{mg} \cdot \mathrm{ml}^{-1}$ of streptomycin. Larvae density was 30 larvae. $\mathrm{ml}^{-1}$ and cultures were fed daily with $10^{7}$ cells of live I. galbana. For each family, one Erlenmeyer flask was inoculated with OsHV-1 homogenate and the other flask was inoculated with the control tissue homogenate (Burge and Friedman, 2012; Renault et al., 2011). Flasks inoculated with OsHV-1 received the equivalent of $10^{9}$ OsHV-1 genome copies. Cultures were sampled at $48 \mathrm{~h}$ post inoculation and the assessment of live/dead larvae was performed using a compound microscope and Sedgewick rafter slide. Aliquots of $10^{3}$ larvae from each culture were pelleted by centrifugation $(1000 \mathrm{~g}, 5 \mathrm{~min})$ and stored at $-80{ }^{\circ} \mathrm{C}$ for subsequent nucleic acid extraction.

To address the specific aims of this study, different fertilization strategies were adopted, as follows:

136 (i) Experiment 1: effect of time between parental immune stimulation and spawning on 137 offspring immunity. 
138 Two cohorts of adult oysters (both males and females) were injected with poly(I:C) at 10 or 3

139 days prior to spawning. A third cohort of adult oysters were injected with sterile seawater at 3

140 days prior to spawning as a control. Up to six pair-mated families were produced for each

141 treatment (Figure 1). Offspring from the 11 pair-mated families were challenged with OsHV-

1421 as described above. In addition to the assessment of survival rates following OsHV-1

143 inoculation, unchallenged offspring from the pair-mated families generated in this experiment

144 was analyzed by RNA-seq and qPCR (sections 2.4 and 2.5). Molecular analyses were

145 performed in order to investigate whether poly(I:C) treatment alters offspring transcriptional 146 responses.

148 (ii) Experiment 2: contribution of maternal and paternal immune stimulation to offspring 149 performance.

150 The role of maternal immune stimulation on offspring immunity to OsHV-1 was examined 151 by mating a single male oyster with five poly(I:C)-treated females and five control (seawater152 injected) females to produce 10-half sibling families that share the same father (Figure 2). 153 Likewise, the role of paternal immune stimulation on offspring immunity was tested by 154 mating a single female oyster with five poly(I:C)-treated males and five seawater-injected 155 males to produce 10 families that share the same mother (Figure 2). Offspring from each 156 family was challenged with OsHV-1 as detailed above.

\subsection{Nucleic acid purification}

159 Total RNA and DNA was isolated using TriReagent ${ }^{\circledR}$ (Sigma-Aldrich) and Isolate II 160 Genomic DNA Kit (Bioline), respectively. Purity and yield of nucleic acids were evaluated 161 using NanoDrop ${ }^{\mathrm{TM}} 2000$ Spectrophometer (Thermo Scientific ${ }^{\mathrm{TM}}$ ). Total RNA (0.5 $\left.\mu \mathrm{g}\right)$ was 162 reverse transcribed using the Tetro cDNA synthesis kit (Bioline) with random hexamers.

\section{3. $O s H V-1$ DNA detection and quantification}

165 Absolute quantification of OsHV-1 DNA was determined by quantitative polymerase chain 166 reaction (qPCR) according to Pepin et al. (2008) using SensiFAST ${ }^{\mathrm{TM}}$ SYBR® No-ROX 167 (Bioline) and the C9/C10 primer pair (Table 1). The concentration of OsHV-1 DNA was 168 estimated from a standard curve generated from the $\mathrm{C} 9 / \mathrm{C} 10$ amplicon product cloned into the 169 pCR4-TOPO vector (Thermo Scientific ${ }^{\mathrm{TM}}$ ) according to the protocols and calculations 170 outlined in the Applied Biosystems manual of absolute real-time RT-PCR quantification 171 (Applied_Biosystems, 2003). The plasmid was diluted in distilled water (Standard Curve: 
172 PCR efficiency $\left.=95 \%, \mathrm{R}^{2}=0.995\right)$ and the dynamic range of the qPCR assay was $10^{8}$ to $10^{3}$ copies.

\subsection{Transcriptome sequencing and differential gene expression}

176 Six larval RNA samples were selected for high-throughput mRNA sequencing (RNA-seq).

177 These samples were from experiment 1 and consisted of three pools (families) of larvae

178 produced from $C$. gigas treated with poly(I:C) and three pools of control larvae. These pools

179 of larvae had not been inoculated with OsHV-1 as we were trying to determine whether 180 unchallenged larvae from poly(I:C)-stimulated parents have a different transcriptome to control larvae. The TruSeq protocol (Illumina), including a poly(A) isolation step, was followed for cDNA synthesis and library preparation. Samples were barcoded and sequenced by the Australian Genome Research Facility (AGRF, Brisbane) on a HiSeq2500 instrument (Illumina) using a $50 \mathrm{bp}$ single end, strand-specific run. The raw sequence reads are available at the National Center for Biotechnology Information (NCBI) Short Read Archive (Accession no. SRP?????).

Nucleotide reads were quality filtered using Trimmomatic (version 0.32) (Bolger, Lohse \& Usadel, 2014) and the quality of the trimmed reads was visualized using fastQC (version 0.10 .1 ). Processed reads from each library were individually mapped back to the

190 GigaTON reference transcriptome for C. gigas (Riviere et al., 2015). The GigaTON transcriptome assembly encompasses a total of 56,621 contigs (median length $=1,659$; N50 $=$ $2,238)$ generated by the combination of 114 RNA-seq libraries, which include an extensive range of developmental stages (e.g. unfertilized eggs, two-cell embryos to two-year-old adults), tissues (e.g. whole-embryos, whole-larvae, whole-spat, gill, hemocyte, mantle, adductor muscle, gonad, digestive tract and labial palp) and physiological conditions (e.g. oysters at ambient conditions and exposed to disturbed temperature, salinity and heavy metals). In addition, mapping of our sequencing reads to the GigaTON transcriptome produced higher alignment rates than the mapping against the $C$. gigas genome (version 101;

19979.4 vs. $66.4 \%$ overall mapping, respectively). The draft genome sequence for $C$. gigas is known to have a number of assembly errors in genome scaffolds (Hedgecock et al., 2015). Therefore, given its complexity and broad genetic diversity, the GigaTON assembly was used as a reference transcriptome in the current study. Mapping of processed reads to the GigaTON assembly was performed using Bowtie2, with strict parameters (-score-minL,-0.1,-

204 0.1, -no-mixed, -no-discordant, -fr -nofw). Assembled contigs were then clustered based on 205 the proportion of shared reads and expression patterns using Corset (default settings) 
(Davidson \& Oshlack, 2014). The cluster-level count data were processed using the edgeR Bioconductor package (Robinson, McCarthy \& Smyth, 2010), testing for differences in gene expression between larvae produced from $C$. gigas treated with poly(I:C) or seawater. Clusters with non-zero counts in at least half of the analyzed samples ( 3 out of 6 samples) were kept for downstream analyses. Data were normalized for sequencing depth (library size) and RNA composition (TMM normalization). Differential expression was calculated using the quantile-adjusted conditional maximum-likelihood method, followed by the exact test.

213 Contigs were considered to be differentially expressed at $p<0.05$ with false detection rate 214 (FDR) lower than 5\%. Differentially expressed genes were annotated using BlastX and the 215 molluca non-redundant (nr) database.

\section{$2.5 R T-q P C R$}

218 To validate the transcriptome data, we evaluated the relative expression profiles of 10 genes identified as differentially expressed by RNA-seq (section 2.4). Annotation could not be assigned to these 10 differentially expressed genes because they matched uncharacterized proteins in the NCBI databases. Genes were chosen for RT-qPCR based on fold change (upor down-regulated) and function (known or unknown). Another 3 antiviral genes (IRF, Viperin and $A D A R-L$ ) were included in this analysis. These genes were not identified to be differentially expressed by RNA-seq, but their expression has been shown to be altered by poly(I:C) treatment and OsHV-1 infection (Green et al., 2015a). The relative expression of these 13 target genes were quantified in cDNA samples from unchallenged eggs and larvae produced from parents stimulated with poly(I:C) or seawater. RT-qPCR was performed in a Green et al. (2016), using the primers in Table 1, which included the internal reference gene eEF1 $\alpha$. Amplification efficiency of each primer pair was validated using a serial dilution of cDNA.

\subsection{Statistical analysis}

Survival and qPCR data were analyzed for statistical differences using analysis of variance (ANOVA) in the SPSS (IBM) version 22.0. Tukey's method for multiple comparisons was used to compare means if significant differences were found $(p<0.05)$. Data that did not meet Levene's test of equal variances was arcsine transformed. Data are presented as mean \pm standard deviation. 


\subsection{Results}

3.1 Effect of time between parental immune stimulation and spawning on offspring immunity

242 The time between parental immune stimulation and spawning had a significant effect on the survival of offspring to OsHV-1 inoculation $\left(\mathrm{F}_{5,28}=10.99, p<0.01\right)$. At $48 \mathrm{~h}$ post-inoculation with OsHV-1, average cumulative mortality of larvae produced from parents stimulated with poly(I:C) at 3 and 10 days prior to spawning was $14.4 \pm 7.2 \%$ and $37.5 \pm 12.2 \%$, respectively. Larvae produced from control parents (injected with seawater at 3 days prespawning) had a cumulative mortality of $45.3 \pm 21.7 \%$ at $48 \mathrm{~h}$ post-inoculation with OsHV-1 (Figure 1). Priming parents with poly(I:C) at 3 days prior to spawning did significantly reduce mortality of larvae compared to controls $(p<0.05)$, but no improvement was observed in larvae generated from parents treated with poly(I:C) at day 10 prior to spawning ( $p>$ 0.05). Priming parents with poly(I:C) had no effect on OsHV-1 replication in larvae. No difference in the amount of OsHV-1 DNA in the tissue of larvae was observed between the three treatments $(p>0.05)$. The mean concentration of OsHV-1 DNA in larvae was $1.2 \times 10^{5}$ and $1.61 \times 10^{5}$ genome copies.larva ${ }^{-1}$ at $48 \mathrm{~h}$ post-inoculation for larvae produced from parents primed with poly(I:C) at 3 and 10 days prior spawning, respectively. Control larvae had $1.1 \times 10^{5}$ genome copies.larva ${ }^{-1}$.

We also investigated whether poly(I:C) stimulation of parents had an effect on survival of non-challenged (NC) larvae. Parental immune stimulation prior to spawning did not effect survival of offspring (Figure $1, p>0.05$ ). The cumulative mortality of larvae at 48 $\mathrm{h}$ post inoculation with the control homogenate was $9.7 \pm 6.9 \%$ and $7.9 \pm 5.3 \%$ for larvae produced from parents stimulated with poly(I:C) at 10 and 3 days prior to spawning, respectively. The cumulative mortality of control larvae was $14.8 \pm 7.5 \%$ at $48 \mathrm{~h}$ post inoculation with the control homogenate. No OsHV-1 DNA was detected in the tissue of larvae exposed to the control homogenate.

\subsection{Effect of maternal and paternal immune stimulation on offspring immunity to Os $H V-1$}

Maternal immune stimulation prior to spawning resulted in $C$. gigas offspring (larvae) with improved immunity to OsHV-1 infection ( $p<0.05$, Figure 2$)$. The average cumulative mortality of larvae produced from poly(I:C) stimulated mothers was $8.3 \pm 5.3 \%$, whereas control larvae had a cumulative mortality 2.3 times higher $(18.9 \pm 6.3 \%)$ at $48 \mathrm{~h}$ postinoculation with OsHV-1. Larvae produced from poly(I:C) stimulated mothers also had

272 significantly lower amounts of OsHV-1 DNA in their tissues compared to control larvae $(p<$ 273 0.05). The average concentration of OsHV-1 DNA in larvae produced from poly(I:C) 
274

275

276

277

278

279

280

281

282

283

284

285

286

287

288

289

290

291

292

293

294

295

296

297

298

299

300

301

302

303

304

305

306

307

stimulated mothers was $4.0 \times 10^{4}$ genome copies per larva, while control larvae had 2.3-fold more OsHV-1 (9.3 x $10^{4}$ copies.larva $\left.^{-1}\right)$ at $48 \mathrm{~h}$ post inoculation.

Paternal immune stimulation prior to spawning had no significant effect on the survival of $C$. gigas offspring to OsHV-1 ( $p>0.05$, Figure 2). The average cumulative mortality of larvae produced from poly(I:C) stimulated fathers was $20.6 \pm 4.6 \%$, whereas control larvae had a cumulative mortality of $31.5 \pm 3.4 \%$ at $48 \mathrm{~h}$ post-inoculation with OsHV-1. There was also no difference in the amount of OsHV-1 DNA in the tissue of Dlarvae produced from poly(I:C) or control stimulated fathers $(p>0.05)$.

Paternal or maternal immune stimulation with poly(I:C) prior to spawning did not affect the survival of non-challenged larvae (i.e. offspring exposed to the control inoculum) $(p>0.05$, Figure 2). Average mortality of larvae in these control treatments was lower than $4 \%$ and OsHV-1 DNA was not detected in their tissue.

\subsection{Differential gene expression in unchallenged larvae following parental immune challenge} RNA-seq was used to investigate whether parental immune stimulation alters the transcription of immune-related genes in offspring. Six cDNA libraries were generated with mRNA from unchallenged D-larvae $(24 \mathrm{~h}$ post-fertilization) produced from parents stimulated with poly(I:C) $(\mathrm{N}=3,3$ days prior to spawning) or seawater $(\mathrm{N}=3)$. Illumina sequencing yielded more than 203 million reads with an average PHRED quality of 37 . The average number of reads was $34 \mathrm{M}$ per library $(\mathrm{SD}=3.3 \mathrm{M} ; \max =37 \mathrm{M} ; \min =28 \mathrm{M})$. Overall, $79.4 \%$ of the total output reads mapped to the GigaTON reference transcriptome $(\mathrm{SD}=7.2 \% ; \max =87.8 \% ; \min =70.8 \%)$. Reads mapped to contigs were clustered into 22,450 gene clusters using Corset. A total of 14,479 (64.5\%) of these gene clusters were present in at least half of the samples sequenced ( 3 out of 6 RNA-seq libraries) and were used for downstream analysis.

Analysis of expression levels for the 14,479 gene clusters revealed that larvae produced from immune-stimulated parents have very similar gene expression profiles to control larvae (Figure 3a). Of the 14,479 gene clusters, only 47 were putatively identified to be differentially expressed (FDR-adjusted, $p<0.05$ ) in D-larvae produced by immunestimulated parents. D-larvae produced from immune-stimulated parents exhibited 22 upregulated genes (fold-change between 2.7 and 302.6) and 25 down-regulated genes (foldchange between -2.9 and -153.1). Blast analysis showed that $87 \%$ of the differentially expressed genes (DEGs; 41 gene clusters) had a significant match against the Mollusca nonredundant (nr) and/or the NCBI nucleotide (nt) databases (e-value $\left.<1^{-10}\right)$. Of the DEGs with 
Blast hits, only $39 \%$ were annotated with a putative gene function. Differentially expressed genes were found to be associated with immune and stress responses (e.g. caspase-14, sacsin, zinc metalloproteinase, F-box only protein 22), cellular signaling and communication (e.g. regulator of G-protein signaling protein, integrin beta pat-3, tenascin and fibrocystin-L), regulation of the cell cycle and cellular division (e.g. nibrin and baculoviral IAP repeatcontaining protein 2) (Figure 3b). We have also identified a number of differentially expressed genes encoding uncharacterized proteins. A few of these uncharacterized proteins exhibited conserved domains, including integrase, reverse transcriptase and recombinase motifs (Table 2).

\subsection{Validation and expression pattern analysis}

A total of 47 DEGs were identified by RNA-seq to be differentially expressed between larvae produced from parents treated with poly(I:C) or seawater (controls) prior to spawning. To validate the RNA-seq analysis, we chose 10 candidate DEGs (25\%) for RT-qPCR analysis. The expression of three known antiviral genes (interferon regulatory factor, Viperin and adenosine deaminase RNA-specific) were also evaluated. RT-qPCR did not identify differences in the expression level of these ten DEGS in groups of larvae produced from parents treated with poly(I:C) or seawater. These samples analysed by RT-qPCR included cDNA sequenced by RNA-seq (experiment I) and cDNA samples from experiment II. Based on these results, we were unable to validate the RNA-seq analysis by RT-qPCR.

The antiviral genes of IRF, viperin and ADAR-L had higher relative expression in eggs from mothers stimulated with poly(I:C) at 3 or 10 days prior to spawning $(p<0.05$, Figure 4a). Higher expression of these genes were also observed in eggs produced by mothers treated with poly(I:C) at 3 days prior to spawning ( $p<0.05$, Figure $4 \mathrm{~b}$ ) but no difference was observed in unchallenged D-larvae produced from parents stimulated with poly(I:C) or seawater $(p>0.05)$.

\section{Discussion}

Heterogeneous immune priming experiments showed that Crassostrea gigas primed with poly(I:C) have improved survival to OsHV-1 infection (Green and Montagnani, 2013; Green et al., 2015b; Lafont et al., 2017), and this protection can be passed to the next generation (Green et al., 2016). Despite the physiological, metabolic and immunological response of $C$.

340 gigas to OsHV-1 infection being well characterized (Corporeau et al., 2014; Green and 341 Speck, 2018; Martenot et al., 2017; Tamayo et al., 2014; Young et al., 2017), relatively little 
is known regarding the molecular mechanisms underpinning the phenomenon of immune priming. A core set of genes expressed in response to OsHV-1 infection has been identified in adults (He et al., 2015; Rosani et al., 2015) and larvae (Zhang et al., 2015), and differences in antiviral gene expression in C. gigas primed with poly(I:C) (Green and Montagnani, 2013; Green et al., 2015b), and their progeny (Green et al., 2016) following inoculation with OsHV-1 have been characterized. Stimulation with double-stranded RNA, such as poly(I:C), induces the expression of antiviral effector genes (Green et al., 2014b), for at least seven days (Green et al., 2014a), and this response appears to inhibit OsHV-1 replication (Lafont et al., 2017; Pauletto et al., 2017). Do C. gigas offspring produced from parents stimulated with poly(I:C) also have elevated expression of antiviral effector genes?

In the current study, oyster larvae had higher survival to OsHV-1 when their mothers, but not their fathers, were administered poly(I:C) prior to spawning (Figure 2). This improved survival could not be explained by reconfiguration of the constitutive expression of antiviral genes in unchallenged larvae. Transcriptomic analysis revealed that non-challenged larvae produced from parents primed with polyI:C have similar transcriptional profiles to control larvae. Despite this overall similarity in transcriptome response, a small subset of 47 genes was found to be differentially regulated between offspring of polyI:C-treated and nontreated parents (Figure 3). However, validation of RNA-seq data by RT-qPCR did not identify any differentially expressed genes between the two offspring cohorts $(21 \%$ of the genes identified by RNA-seq were tested by RT-qPCR). This discrepancy might be caused by the small sample sizes $(\mathrm{N}=3)$ used in the current study. Alternatively, our results imply that the improved survival of $C$. gigas larvae might occur via maternal provisioning of antiviral compounds in the eggs. In support of maternal provisioning is the up-regulation of antiviral effector genes, including viperin, in the eggs of $C$. gigas following stimulation with poly(I:C) (Figure 4). Viperin has been shown to be induced by poly(I:C) treatment via a hemolymph cytokine and to play a direct role in oyster antiviral defense (Green et al., 2015c). Maternal provisioning is consistent with a previous study on the scallop Chlamys farreri, where mothers stimulated with heat-killed Vibrio transfer antibacterial proteins to their offspring via the egg (Yue et al., 2013). Crosses involving OsHV-1 infected C. gigas mothers produce progengy (larvae and spat developmental life-stages) have survival rates statistically higher than other types of crosses, suggesting OsHV-1 infection mothers transmit some form of protection to their offspring (Barbosa-Solomieu et al., 2005). advantage that it is the mother, not the developing embryo, who invests resources into its 
offspring's antiviral defense. Immunity is a life-history trait that can be expected to be traded

377

378

379

380

381

382

383

384

385

386

387

388

389

390

391

392

393

394

395

396

397

398

399

400

401

402

403

404

405

406

407

408

409

off with other physiological processes, such as growth, reproduction and self-maintenance (Rauw, 2012). Immune activation entails a significant energetic cost, revealed by raised metabolic rates between $8-28 \%$ in a range of terrestrial insects following PAMP inoculation or injury (Ardia et al., 2012; Freitak et al., 2003). The metabolic requirement of immunity has not been quantified for marine bivalves, but it is likely to have a similar high cost. During early larval development of $C$. gigas, activating an immune response can compromise other physiological processes. In ideal environmental conditions, C. gigas larvae allocate $\sim 75 \%$ of their total metabolic energy budget to protein synthesis $(\sim 55 \%)$ and ion transport $(\sim 20 \%)$ (Lee et al., 2016; Pan et al., 2016). Thus, maternal provisioning of immunity represents a beneficial investment from mother to offspring, reducing the cost of producing and maintaining an expensive antiviral response. It now needs to be determined if this antiviral immunity persists or declines during $C$. gigas embryonic developments, as the antiviral compounds are metabolized.

Selective breeding programs in many countries have developed improved C. gigas stocks, which are better suited for aquaculture purposes (de Melo et al., 2016; Degremont et al., 2015a; Swan et al., 2007). Indeed, survival to OsHV-1 infection is a trait that has received considerable scientific attention given the benefits it could provide to oyster production worldwide (Camara et al., 2017; Dégremont, 2011; Degremont et al., 2015b). To access genetically improved $C$. gigas stocks, shellfish farms have to source spat from aquaculture hatcheries (Robert and Gerard, 1999). However, aquaculture hatchery supply of C. gigas spat is inconsistent due to larval mortality events (Robert and Gerard, 1999), which can be caused by OsHV-1 (Barbosa-Solomieu et al., 2005; Hine et al., 1992; Renault et al., 2000). Our results demonstrate that it is possible to utilize transgenerational immune priming to reduce mortalities in hatchery production of $C$. gigas, thus challenging the concept that such therapies cannot be adapted for oyster aquaculture (Pernet et al., 2016; Rodgers et al., 2018). This study also showed that transgenerational immune priming against OsHV-1 is consistently reproducible, alleviating the concerns surrounding the existence of immune priming in shellfish (Hauton and Smith, 2007). Future research should focus on characterizing the transfer of antiviral compounds from mother to offspring. The application of this knowledge can have great potential for improving oyster health and welfare in aquaculture.

\section{Competing interests}


410 The authors declare no competing interests.

411

\section{Acknowledgement}

413 The authors acknowledge funding provided to T. Green from the Macquarie University

414 postdoctoral research scheme (MQ Grant 9201300681), Canada Research Chair Program

415 (Grant No. 950-231856) and NSERC Discovery Grant (RGPIN-2018-06761). The authors

416 are grateful for a travel bursary to M. Lafont from IFREMER.

417

\section{References}

419 Applied_Biosystems, 2003. Creating standard curves with genomic DNA or plasmid DNA templates for use in quantitative PCR. http://www.appliedbiosystems.com/support/tutorials/pdf/quant_pcr.pdf.

422

423

424

425

426

427

428

429

430

431

432

433

434

435

436

437

438

439

440

441

442

443

444

445

446

Ardia, D., Gantz, J.E., Schneider, B.C., Strebel, S., 2012. Costs of immunity in insects: an induced immune responses increases metabolic rate and decreases antimicrobial activity. Funct. Ecol. 26, 732-739.

Barbosa-Solomieu, V., Degremont, L., Vazquez-Juarez, R., Ascencio-Valle, F., Boudry, P., Renault, T., 2005. Ostreid herpesvirus 1 (OsHV-1) detection among three successive generations of Pacific oysters (Crassostrea gigas). Virus Res. 107, 47-56.

Barribeau, S.M., Schmid-Hempel, P., Sadd, B.M., 2016. Royal decree: gene expression in trans-generationally immune primed bublebee workers mimics a primary immune response. PLoS ONE 11.

Benkendorff, K., Davis, A.R., Bremner, J.B., 2001. Chemical defense in the egg masses of benthic invertebrates: an assessment of antibacterial activity in 39 mollusks and 4 polychaetes. J. Invert. Pathol. 78, 109-118.

Burge, C.A., Friedman, C.S., 2012. Quantifying ostreid herpesvirus (OsHV-1) genome copies and expression during transmission. Microb Ecol.

Burge, C.A., Griffin, F.J., Friedman, C.S., 2006. Mortality and herpesvirus infections of the Pacific oyster Crassostrea gigas in Tomales Bay, California, USA. Dis. Aquat. Org. 72, 3143.

Camara, M.D., Yen, S., Kaspar, H.F., Kesarcodi-Watson, A., King, N., Jeffs, A.G., Tremblay, L.A., 2017. Assessment of heat shock and laboratroy virus challenges to selectively breed for ostreid herpesvirus 1 (OsHV-1) resistance in the Pacific oyster, Crassostrea gigas. Aquaculture 469, 50-58.

Castro-Vargas, C., Linares-Lopez, C., Lopez-Torres, A., Wrobel, K., Torres-Guzman, J.C., Hernandez, G.A.G., Wrobel, K., Lanz-Mendoz-H., Contreras-Garduno, J., 2017. Methylation on RNA: a potential mechanism related to immune priming within but not across generations. Front. Microbiol. 8, 473. 
Chang, Y.-H., Kumar, R., Ng, T.H., Wang, H.-C., 2018. What vaccination studies tell us about immunological memory within the innate immune system of cultured shrimp and crayfish. Dev. Comp. Immunol. 80, 53-66.

Contreras-Garduno, J., Lanz-Mendoza, H., Franco, B., Nava, A., Pedraza-Reyes, M., Canales-Lazcano, J., 2016. Insect immune priming: ecology and experimental evidences. Ecological Entomology 41, 351-366.

Corporeau, C., Tamayo, D., Pernet, F., Quere, C., Madec, S., 2014. Proteomic signatures of the oyster metabolic response to herpesvirus OsHV-1 $\mu$ var infection. J. Proteomics.

de Melo, C.M.R., Durland, E., Langdon, C., 2016. Improvements in desirable traits of the Pacific oyster, Crassostrea gigas, as a result of five generations of selection on the West Coast, USA. Aquaculture 460, 105-115.

Dégremont, L., 2011. Evidence of herpesvirus (OsHV-1) resistance in juvenile Crassostrea gigas selected for high resistance to the summer mortality phenomenon. Aquaculture 317, 94-98.

Degremont, L., Garcia, C., Allen Jr, S.K., 2015a. Genetic improvement for disease resistance in oysters: a review. J. Invert. Pathol. 131, 221-241.

Degremont, L., Lamy, J.-B., Pepin, J.-F., Travers, M.-A., Renault, T., 2015b. New insight for the genetic evaluation of resistance to Ostreid herpesvirus infection, a worldwide disese, in Crassostrea gigas. Plos One 10, e0127917.

Eggert, H., Kurtz, J., Diddens-de Buhr, M.F., 2014. Different effects of paternal transgenerational immune priming on survival and immunity in step and genetic offspring. Proc. R. Soc. B 281, 20142089.

Evans, O., Hick, P., Whittington, R.J., 2017. Detection of Ostreid herpesvirus-1 microvariants in healthy Crassostrea gigas following disease events and their possible role as reservoirs of infection. J. Invert. Pathol. 148, 20-33.

Freitak, D., Ots, I., Horak, P., 2003. Immune response is energetically costly in white cabbage butterfly pupae. Proc. Biol. Sci. 270, S220-S222.

Freitak, D., Schmidtberg, H., Dickel, F., Lochnit, G., Vogel, H., Vilcinskas, A., 2014. The maternal transfer of bacteria can mediate trans-generational immune priming in insects. Virulence 5, 1-8.

Go, J., Deutscher, A.T., Spiers, Z.B., Dahle, K., Kirkland, P.D., Jenkins, C., 2017. Mass mortalities of unknown aetiology in Pacific oysters Crassostrea gigas in Port Stephens, New South Wales, Australia. Dis Aquat Org 125, 227-242.

Green, T.J., Benkendorff, K., Robinson, N., Raftos, D., Speck, P., 2014a. Anti-viral gene induction is absent upon secondary challenge with double-stranded RNA in the Pacific oyster, Crassostrea gigas. Fish Shellfish Immunol. 39, 492-497.

Green, T.J., Helbig, K.J., Speck, P., Raftos, D.A., 2016. Primed for success: oyster parents treated with poly(I:C) produce offspring with enhanced protection against Ostreid herpesvirus type I infection. Mol. Immunol. 78, 113-120. 
Green, T.J., Montagnani, C., 2013. Poly I:C induces a protective antiviral immune response in the Pacific oyster (Crassostrea gigas) against subsequent challenge with Ostreid herpesvirus (OsHV-1 $\mu$ var). Fish Shellfish Immunol. 35, 382-388.

Green, T.J., Montagnani, C., Benkendorff, K., Robinson, N., Speck, P., 2014b. Ontogeny and water temperature influences the antiviral response of the Pacific oyster, Crassostrea gigas. Fish Shellfish Immunol. 36, 151-157.

Green, T.J., Raftos, D.A., Speck, P., Montagnani, C., 2015a. Antiviral immunity in marine molluscs. J. Gen. Virol. 96, 2471-2482.

Green, T.J., Rolland, J.-L., Vergnes, A., Raftos, D.A., Montagnani, C., 2015b. OsHV-1 countermeasures to the Pacific oyster's anti-viral response. Fish Shellfish Immunol. 47, 435443.

Green, T.J., Speck, P., 2018. Antiviral defense and innate immune memory in the oyster. Viruses 10, 133.

Green, T.J., Speck, P., Geng, D., Raftos, D.A., Beard, M.R., Helbig, K.J., 2015c. Oyster viperin retains direct antiviral activity and its transcription occurs via a signalling pathway involving a heat-stable hemolymph protein. J. Gen. Virol. 96, 3587-3597.

Hauton, C., Smith, V.J., 2007. Adaptive immunity in invertebrates: a straw house without a mechanistic foundation. BioEssays 29, 1138-1146.

He, Y., Jouaux, A., Ford, S.E., Lelong, C., Sourdaine, P., Mathieu, M., Guo, X., 2015. Transcriptome analysis reveals strong and complex antiviral response in a mollusc. Fish Shellfish Immunol. 46, 131-144.

Hedgecock, D., Shin, G., Gracey, A.Y., Van Den Berg, D., Samanta, M.P., 2015. Secondgeneration linkage maps for the Pacific oyster Crassostrea gigas reveal errors in assembly of genome scaffolds. G3 10.1534/g3.115.019570

Hernandez Lopez, J., Schuehly, W., Crailsheim, K., Riessberger-Galle, U., 2014. Transgenerational immune priming in honeybees. Proc. R. Soc. B 281, 20140454.

Hick, P., Evans, O., Looi, R., English, C., Whittington, R.J., 2016. Stability of Ostreid herpesvirus-1 (OsHV-1) and assessment of disinfection of seawater and oyster tissues using a bioassay. Aquaculture 450, 412-421.

Hine, P.M., Wesney, B., Hay, B.E., 1992. Herpesvirus associated with mortalities among hatchery-reared larval Pacific oysters Crassostrea gigas. Dis. Aquat. Org. 12, 135-142.

Jenkins, C., Hick, P., Gabor, M., Spiers, Z., Fell, S.A., Gu, X., Read, A., Go, J., Dove, M., O'Connor, W., Kirkland, P.D., Frances, J., 2013. Identification and characterisation of an ostreid herpesvirus-1 microvariant (OsHV-1 u-var) in Crassostrea gigas (Pacific oysters) in Australia. Dis. Aquat. Org. 105, 109-126.

Keeling, S.E., Brosnahan, C.L., R., W., Gias, E., Hannah, M., Bueno, R., McDonald, W.L., Johnston, C., 2014. New Zealand juvenile oyster mortality associated with ostreid herpesvirus 1 - an opportunisitic longitudinal study. Dis. Aquat. Org. 109, 231-239. 
Kurtz, J., Franz, K., 2003. Evidence for memory in invertebrate immunity. Nature 425, 3738.

526 Lafont, M., Petton, B., Vergnes, A., Pauletto, M., Segarra, A., Gourbal, B., Montagnani, C., 2017. Long-lasting antiviral innate immune priming in the Lophotrochozoan Pacific oyster, Crassostrea gigas. Sci. Rep. 7, 13143.

Lee, J.W., Applebaum, S.L., Manahan, D.T., 2016. Metabolic cost of protein synthesis in larvae of the Pacific oyster (Crassostrea gigas) is fixed across genotype, phenotype, and environmental temperature. Biol. Bull. 230, 175-187.

Little, T.J., O'Connor, B., Colegrave, N., Watt, K., Read, A.F., 2003. Maternal transfer of strain-specific immunity in an invertebrate. Curr. Biol. 13, 489-492.

Martenot, C., Gervais, O., Chollet, B., Houssin, M., Renault, T., 2017. Haemocytes collected from experimentally infected Pacific oysters, Crassostrea gigas: Detection of ostreid herpesvirus 1 DNA, RNA, and proteins in relation with inhibition of apoptosis. PLoS ONE $12, \mathrm{e} 0177448$.

McNamara, K.B., Van Lieshout, E., Simmons, L.W., 2014. The effect of maternal and paternal immune challenge on offspring immunity and reproduction in a cricket. J. Evol. Biol. 27, 1020-1028.

Milutinovic, B., Kurtz, J., 2016. Immune memory in invertebrates. Sem. Immunol. 28, 328342 .

Norouzitallab, P., Baruah, K., Biswas, P., Vanrompay, D., Bossier, P., 2016. Probing the phenomenon of trained immunity in invertebrates during a transgenerational study, using brine shrimp Artemia as a model system. 6, 21166.

Pan, F.T.-C., Applebaum, S.L., Lentz, B.A., Manahan, D.T., 2016. Predicting phenotypic variation in growth and metabolism of marine invertebrate larvae. J. Exp. Mar. Biol. 483, 6473.

Paul-Pont, I., Evans, O., Dhand, N.K., Rubio, A., Coad, P., Whittington, R., 2014. Descriptive epidemiology of mass mortality due to Ostreid herpesvirus-1 (OsHV-1) in commercially farmed Pacific oysters (Crassostrea gigas) in the Hawkesbury River estuary, Australia. Aquaculture 422, 146-159.

Pauletto, M., Segarra, A., Montagnani, C., Quillien, V., Faury, N., Le Grand, J., Miner, P., Petton, B., Labreuche, Y., Fleury, E., Fabioux, C., Bargelloni, L., Renault, T., Huvet, A., 2017. Long dsRNAs promote an anti-viral response in Pacific oyster hampering ostreid herpesvirus 1 replication. J. Exp. Biol. 220, 3671-3685.

Pernet, F., Barret, J., Le Gall, P., Corporeau, C., LDegremont, L., Lagarde, F., Pepin, J.F., Keck, N., 2012. Mass mortalities of Pacific oysters Crassostrea gigas reflect infectious diseases and vary with farming practices in the Mediterranean Thau lagoon, France. Aquaculture Environ Interact 2, 215-237.

Pernet, F., Lupo, C., Bacher, C., Whittington, R.J., 2016. Infectious disease in oyster aquaculture require a new integrated approach. Phil. Trans. R. Soc. B. 371, 20150213. 
Rauw, W.M., 2012. Immune response from a resource allocation perspective. Front. Genet. 3, 267.

565 Renault, T., Cochennec, N., Le Deuff, R.-M., Chollet, B., 1994. Herpes-like virus infecting

566 Japanese oyster (Crassostrea gigas) spat. Bull. Eur. Assoc. Fish Pathol. 14, 64-66.

567 Renault, T., Faury, N., Barbosa-Solomieu, V., Moreau, K., 2011. Suppression substractive

568 hybridisation ( $\mathrm{SSH}$ ) and real time PCR reveal differential gene expression in the Pacific cupped oyster, Crassostrea gigas, challenged with Ostreid herpesvirus 1. Dev. Comp.

570 Immunol. 35, 725-735.

571

572

573

574

575

576

577

578

579

580

581

582

583

584

585

586

587

588

589

590

591

592

593

594

595

596

597

598

599

600

601

Renault, T., Le Deuff, R.-M., Chollet, B., Cochennec, N., Gerard, A., 2000. Concomitant herpes-like virus infections in hatchery-reared larvae and nursery-cultured spat Crassostrea gigas and Ostrea edulis. Dis. Aquat. Org. 42, 173-183.

Riviere, G., Klopp, C., Ibouniyamine, N., Huvet, A., Boudry, P., Favrel, P., 2015. GigaTON: an extensive publicly searchable database providing a new reference transcriptome in the Pacific oyster Crassostrea gigas. BMC Bioinformatics 16, 401.

Robert, R., Gerard, A., 1999. Bivalve hatchery technology: the current situation for the Pacific oyster Crassostrea gigas and the scallop Pecten maximus in France. Aquat. Living Resour. 12, 121-130.

Rodgers, C., Arzul, I., Carrasco, N., Furones Nozal, D., 2018. A literature review as an aid to identify strategies for mitigating ostreid herpesvirus 1 in Crassostrea gigas hatchery and nursery systems. Rev. Aquacult. https://doi.org/10.1111/raq.12246, 1-21.

Rosani, U., Varotto, L., Domeneghetti, S., Arcangeli, G., Pallavicini, A., Venier, P., 2015. Dual analysis of host and pathogen transcriptomes in Ostreid herpesvirus 1 - positive Crassostrea gigas. Environ. Microbiol. 17, 4200-4212.

Roth, O., Joop, G., Eggert, H., Hilbert, J., Daniel, J.-Y., Schmid-Hempel, P., Kurtz, J., 2010. Paternally derived immune priming for offspring in the red flour beetle, Tribolium castaneum. J. Anim. Ecol. 79, 403-413.

Sadd, B.M., Kleinlogel, Y., Schmid-Hempel, R., Schmid-Hempel, P., 2005. Transgenerational immune priming in a social insect. Biol. Lett. 1, 386-388.

Segarra, A., Pepin, J.F., Arzul, I., Morga, B., Faury, N., Renault, T., 2010. Detection and description of a particular Ostreid herpesvirus 1 genotype associated with massive mortality outbreaks of Pacific oysters, Crassostrea gigas, in France in 2008. Virus Res. 153, 92-99.

Swan, A.A., Thompson, P.A., Ward, R.D., 2007. Genotype x environment interactions for weight in Pacific oysters (Crassostrea gigas) on five Australian farms. Aquaculture 265, 91101.

Tamayo, D., Corporeau, C., Petton, B., Quere, C., Pernet, F., 2014. Physiological changes in Pacific oyster Crassostrea gigas exposed to the herpesvirus OsHV-1 uvar. Aquaculture 432, 304-310.

Wang, L., Yue, F., Song, X., Song, L., 2015. Maternal immune transfer in mollusc. Dev. Comp. Immunol. 48, 354-359. 
602 Whittington, R.J., Dhand, N.K., Evans, O., Paul-Pont., I., 2015. Further observations on the 603 influence of husbandry practives on OsHV-1 uVar mortality in Pacific oysters Crassostrea

604 gigas: age, cultivation structures and growing height. Aquaculture 438, 82-97.

605 Young, T., Kesarcodi-Watson, A., Alfaro, A.C., Merien, F., Nguyen, T.V., Mae, H., Le,

606 D.V., Villas-Boas, S., 2017. Differential expression of novel metabolic and immunological

607 biomarkers in oysters challenged with a virulent strain of OsHV-1. Dev. Comp. Immunol. 73,

608 229-245.

609 Yue, F., Zhou, Z., Wang, L., Ma, Z., Wang, J., Wang, M., Zhang, H., Song, L., 2013.

610 Maternal transfer of immunity in scallop Chlamys farreri and its trans-generational immune

611 protection to offspring against bacterial challenge. Dev. Comp. Immunol. 41, 569-577.

612 Zanchi, C., Troussard, J.-P., Martinaud, G., Moreau, J., Moret, Y., 2011. Differential

613 expression and costs between maternally and paternally derived immune priming for

614 offspring in an insect. Journal of Animal Ecology 80, 1174-1183.

615 Zhang, L., Li, L., Guo, X., Litman, G.W., Dishaw, L.J., Zhang, G., 2015. Massive expansion

616 and functional divergence of innate immune genes in a protostome. Sci. Rep. 5, 1-11.

617

618 Tables

619 Table 1: Primer pairs used for qPCR analysis. Genes in bold are known internal reference

620 genes or antiviral proteins selected from the scientific literature. The closest match in the

621 NCBI mollucan database (BlastX) and its annotation is provided.

\begin{tabular}{lllll}
\hline Cluster & Genbank Match & Sense Primer & Antisense Primer & Annotation \\
\hline EFU & ABI22066 & GAGCGTGAACGTGGTATCAC & ACA GCA CAG TCA GCC TGT GA & Internal Reference Gene \\
Cluster-9448.0 & XP_01142697 & ATC GAA TGT AAA TGT ATG ACC AC & TTG ATC GGT GCA GTG TCT G & \\
Cluster-14532.0 & XP_011427757 & ACT GCA CTC GAT CCA AGA TG & AGA TAC ATT CAT CAT ACG GAC TG \\
Cluster-5145.0 & XP_011422960 & AGA GCC AAT GAT ATC ACA TGA G & TGT AGC AGC TTT CCC ATC TG \\
Cluster-162.2748 & EKC32605 & GTC TAT TTA CGG ACT TGC TAA C & GAG TCG TCG CAT CGT TAC & TCT CTT AGC ACA GTC ACT AG \\
Cluster-10608.0 & XP_011451618 & ATC CAG GAC GCG GTA GAG & TCT GGT GAC GAA GCT GGT G & ACAC TTT GGT GTG CGC AAG \\
Cluster-3884.0 & XP_011441565 & ACA GCA AAC ATG TGT CCA AG & TGC & CAT TCA CCA CAC TCC ATT CTG \\
Cluster-7150.0 & NO ID & TGC TGT AAA GTT CTT GCA TC & AGT AGC GAC CGA CTT CAG TC & Antiviral Signaling \\
Cluster-13785.3 & NO ID & GTA GGA TGG TAA AGT GCA CAG & GAT AAC TCT TCC TTC CCA GAC \\
Cluster-4797.0 & XP_011445587 & ACC TGT TTG GAG CAG TGT C & ATT TGC CTT CCA TCT TTT GG \\
Cluster-162.3841 & XP_011450578 & GTC ACT TTT GCT CAG CTG ATG & TGiviral Effector \\
IRF & EKC43155 & CGA AAC GCA GAA ACT GTT C & Antiviral Effector \\
Viperin & EKC28205 & GCT TTG ACC CGG AAA CCA AC & TCA CAA GCC CTG CTA TCA C & OsHV-1 quantification \\
ADAR & EKC20855 & CTC AAA CAG TGC AAC TGC ATC & ATC ACC GGC AGA CGT AGG &
\end{tabular}

623 
624 Table 2: Genes identified by RNA-seq to be differentially expressed between larvae produced

625 from broodstock stimulated with poly(I:C) or seawater. Genes highlighted in bold were

626 investigated by RT-qPCR.

\begin{tabular}{|c|c|c|c|c|c|}
\hline Cluster ID & FC & PValue & FDR & BlastX & Annotation \\
\hline Cluster-3884.0 & 302.62 & 3.28781E-29 & $4.76042 \mathrm{E}-25$ & XP_011441565 & Uncharaterized Protein \\
\hline Cluster-14532.0 & 70.02 & 7.1539E-19 & $3.45271 \mathrm{E}-15$ & XP_011427757 & Caspase-14-like protein \\
\hline Cluster-162.709 & 42.48 & $8.86638 \mathrm{E}-11$ & $1.60 \mathrm{E}-07$ & XP_011433740 & Integrin beta containing protein \\
\hline Cluster-5194.0 & 33.92 & 7.85977E-15 & $2.85 \mathrm{E}-11$ & XP_011431106 & Uncharaterized Protein \\
\hline Cluster-9448.0 & 24.53 & $4.4828 \mathrm{E}-19$ & $3.25 E-15$ & XP_011426297 & Uncharaterized Protein \\
\hline Cluster-26.1 & 17.06 & 8.98332E-09 & $1.08391 \mathrm{E}-05$ & XP_019927010 & sacsin-like protein \\
\hline Cluster-8341.0 & 15.81 & 5.77909E-09 & 7.61E-06 & No Match & Hypothetical Protein \\
\hline Cluster-2997.1 & 10.58 & $2.27381 \mathrm{E}-09$ & $3.65806 \mathrm{E}-06$ & XP_019921756 & E3 ubiquitin-protein ligase \\
\hline Cluster-9682.0 & 8.77 & $2.88696 \mathrm{E}-06$ & 0.001990491 & No Match & Hypothetical Protein \\
\hline Cluster-806.0 & 8.18 & 6.64977E-05 & $2.29 \mathrm{E}-02$ & No Match & Hypothetical Protein \\
\hline Cluster-162.3691 & 8.14 & $2.81483 \mathrm{E}-09$ & $4.08 \mathrm{E}-06$ & EKC28297 & Hypothetical Protein \\
\hline Cluster-1784.1 & 7.11 & 1.88997E-05 & $8.83 \mathrm{E}-03$ & XP_011415777 & Uncharaterized Protein \\
\hline Cluster-4559.0 & 6.94 & $4.33946 \mathrm{E}-05$ & $1.65 \mathrm{E}-02$ & EKC27857 & EGF-like domain containing protein \\
\hline Cluster-13205.0 & 6.51 & $2.96782 \mathrm{E}-05$ & $1.19 \mathrm{E}-02$ & XP_019919735 & Uncharaterized Protein \\
\hline Cluster-10168.0 & 5.99 & $1.18908 \mathrm{E}-12$ & $2.46 \mathrm{E}-09$ & EKC37705 & Hypothetical Protein \\
\hline Cluster-71.0 & 5.99 & $1.29584 \mathrm{E}-06$ & 0.001103675 & XP_011447098 & Zinc finger containing protein \\
\hline Cluster-6742.0 & 5.67 & $9.20341 \mathrm{E}-06$ & $5.13 \mathrm{E}-03$ & EKC22504 & Hypothetical Protein \\
\hline Cluster-8759.0 & 4.26 & 0.000152333 & 0.046928379 & XP_011425705 & Uncharaterized Protein \\
\hline Cluster-9418.0 & 3.21 & $5.42253 \mathrm{E}-05$ & 0.020131487 & EKC21305 & Hypothetical Protein \\
\hline Cluster-2485.0 & 3.07 & $9.38279 \mathrm{E}-05$ & 0.030875788 & XP_011416425 & Perlucin-like protein \\
\hline Cluster-4860.0 & 3.03 & 0.000139626 & 4.39E-02 & EKC35803 & Hypothetical Protein \\
\hline Cluster-6877.3 & 2.74 & $2.50613 \mathrm{E}-05$ & $1.07 \mathrm{E}-02$ & XP_011456604 & Ribonucleoside diphosphate reductase \\
\hline Cluster-162.3562 & 0.34 & $7.82385 \mathrm{E}-05$ & 2.63E-02 & XP_019929668 & Uncharaterized Protein \\
\hline Cluster-13785.3 & 0.27 & 2.48153E-06 & $1.80 \mathrm{E}-03$ & No Match & Hypothetical Protein \\
\hline Cluster-1470.0 & 0.27 & $5.68381 \mathrm{E}-05$ & $2.06 \mathrm{E}-02$ & EKC20054 & Cleavage Stimulation Factor 77kDa \\
\hline Cluster-10608.0 & 0.20 & 1.39379E-05 & 7.21E-03 & XP_011451618 & Uncharaterized Protein \\
\hline Cluster-162.2025 & 0.20 & 2.13317E-05 & 0.009651932 & XP_011437445 & Baculoviral IAP repeat protein \\
\hline Cluster-162.946 & 0.19 & 0.000115807 & 0.037261697 & EKC27582 & Tripartite motif protein 2 \\
\hline Cluster-162.639 & 0.18 & $2.10392 \mathrm{E}-06$ & 0.001603299 & XP_019922312 & Nibrin-like protein \\
\hline Cluster-162.3841 & 0.17 & 2.4699E-05 & 1.07E-02 & XP_011450578 & Uncharaterized Protein \\
\hline Cluster-4685.0 & 0.16 & $6.68718 \mathrm{E}-06$ & $4.03 \mathrm{E}-03$ & XP_011446049 & Fibrocystin-L-like protein \\
\hline Cluster-4797.0 & 0.15 & $3.23101 E-06$ & 0.002126448 & XP_011445587 & Uncharaterized Protein \\
\hline Cluster-2950.0 & 0.14 & $1.53162 \mathrm{E}-05$ & 7.44E-03 & ЕКС39917 & Fibrocystin-L-like protein \\
\hline Cluster-7150.0 & 0.13 & 1.00793E-06 & $9.12 \mathrm{E}-04$ & No Match & Hypothetical Protein \\
\hline Cluster-5881.0 & 0.13 & $1.03442 \mathrm{E}-05$ & 0.005547163 & XP_019928976 & Uncharaterized Protein \\
\hline Cluster-162.2272 & 0.12 & $6.47005 \mathrm{E}-05$ & $2.28 \mathrm{E}-02$ & EKC37905 & EGF-like domain containing protein \\
\hline Cluster-6413.0 & 0.10 & $4.4625 \mathrm{E}-08$ & 4.61518E-05 & XP_011413924 & Uncharaterized Protein \\
\hline Cluster-162.1461 & 0.10 & 3.21255E-05 & $1.26 \mathrm{E}-02$ & EKC20083 & F-box only protein 22 \\
\hline Cluster-8476.1 & 0.09 & $1.85335 \mathrm{E}-07$ & 0.000178897 & XP_011433732 & Zinc finger containing protein \\
\hline Cluster-13153.0 & 0.08 & $2.76871 \mathrm{E}-05$ & $1.15 \mathrm{E}-02$ & ЕКС33341 & Hypothetical Protein \\
\hline Cluster-13573.0 & 0.07 & $1.57403 \mathrm{E}-14$ & $4.56 \mathrm{E}-11$ & EKC40398 & SEC7 domain-containing protein \\
\hline Cluster-3702.0 & 0.07 & 7.75681E-06 & 4.49E-03 & XP_011447229 & Zinc metalloproteinase \\
\hline Cluster-5145.0 & 0.04 & $5.21847 \mathrm{E}-13$ & 1.2593E-09 & XP_011422960 & Uncharaterized Protein \\
\hline Cluster-162.2749 & 0.04 & 4.12664E-06 & $2.60 \mathrm{E}-03$ & XP_011453448 & Uncharaterized Protein \\
\hline
\end{tabular}




\begin{tabular}{lrrrll} 
Cluster-162.2748 & $\mathbf{0 . 0 4}$ & $\mathbf{2 . 0 5 0 8 4 E - 0 6}$ & $\mathbf{1 . 6 0 E - 0 3}$ & EKC32605 & Tenascin-N \\
Cluster-14227.0 & 0.02 & $2.367 \mathrm{E}-08$ & $2.64 \mathrm{E}-05$ & XP_011413410 & G-protein \\
Cluster-162.3084 & 0.01 & $1.54057 \mathrm{E}-05$ & $7.44 \mathrm{E}-03$ & No Match & Hypothetical Protein \\
\hline
\end{tabular}

\section{Figure Legends}
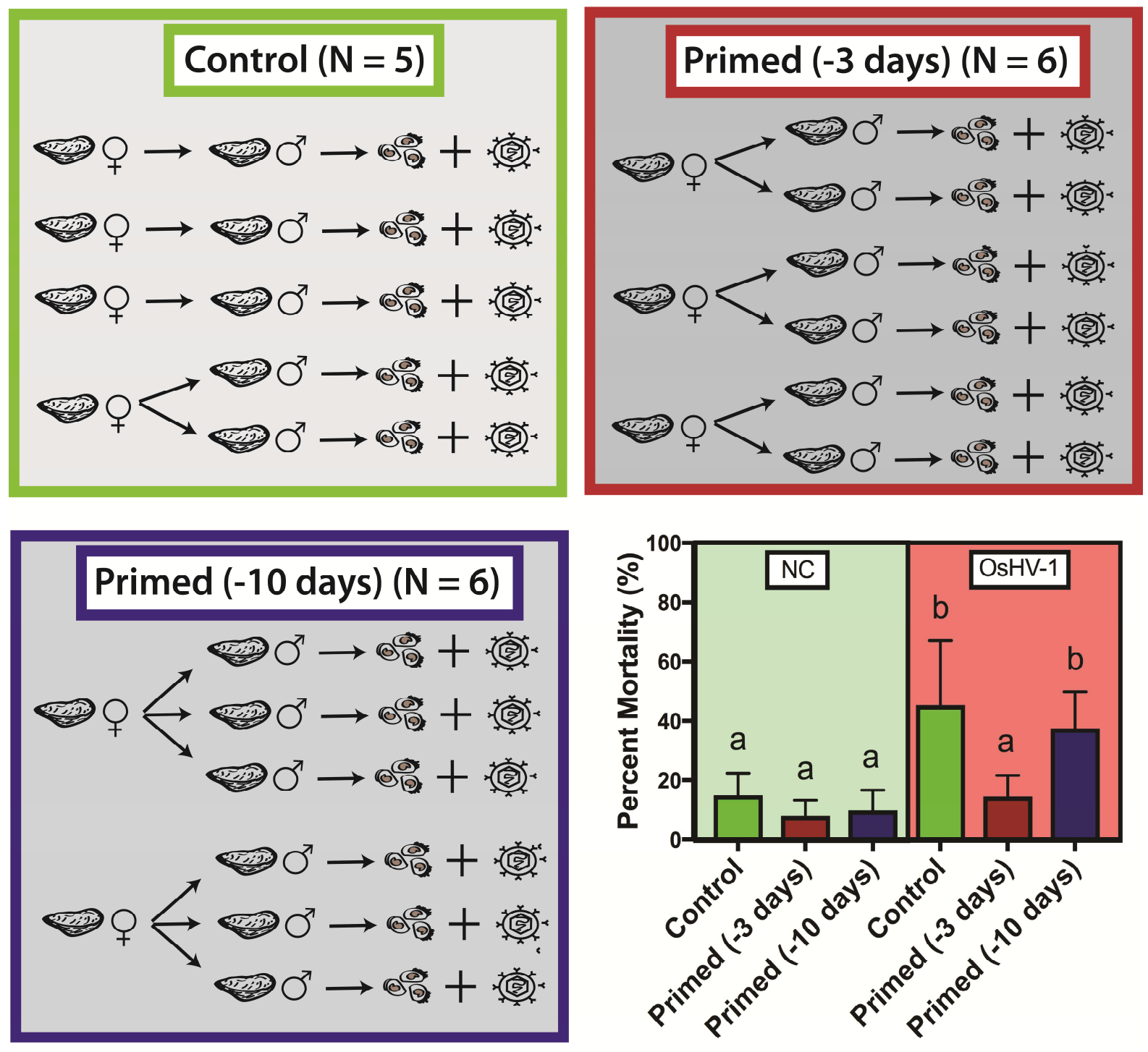

631 Figure 1: Schematic diagram of experimental design for investigating the effect of time

632 between parental immune stimulation and spawning on offspring immunity to OsHV-1. Two

633 cohorts of adult Crassostrea gigas were injected with poly(I:C) at 3 and 10 days prior to

634 spawning. A third cohort of $C$. gigas were injected with seawater. Up to 6 pair mated families

635 were produced for each treatment. D-larvae from each family were inoculated with OsHV-1

636 or control homogenate (NC). Cumulative mortality for each treatment was determined at 48

637 hours post-inoculation (mean \pm standard deviation). Different letters indicate significant

638 differences $(p<0.05)$ between treatments. 
a)

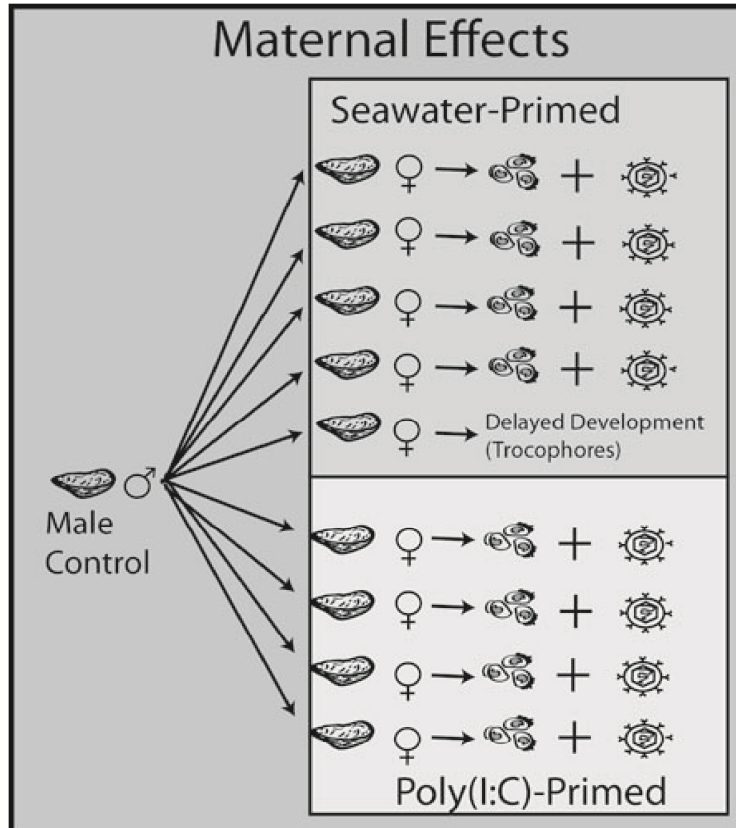

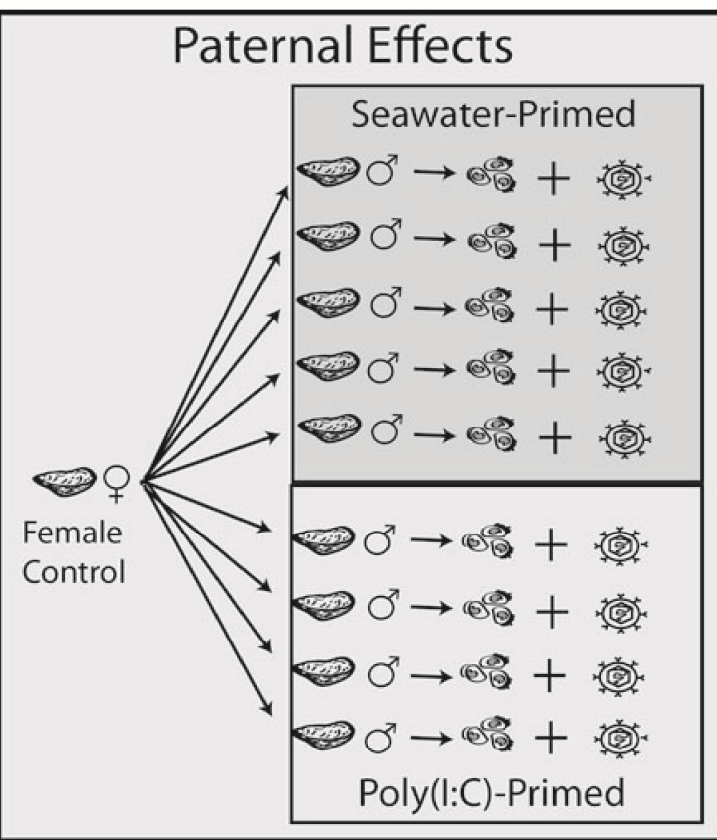

b)
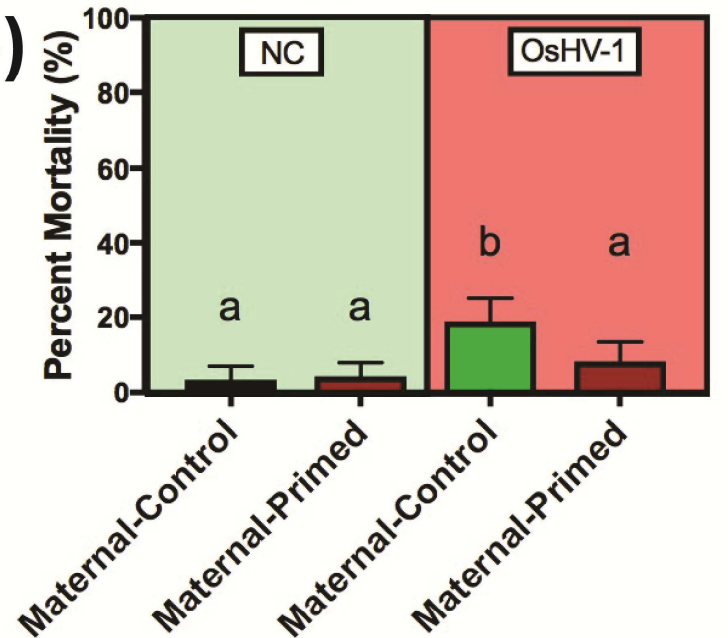

Maternal Effects

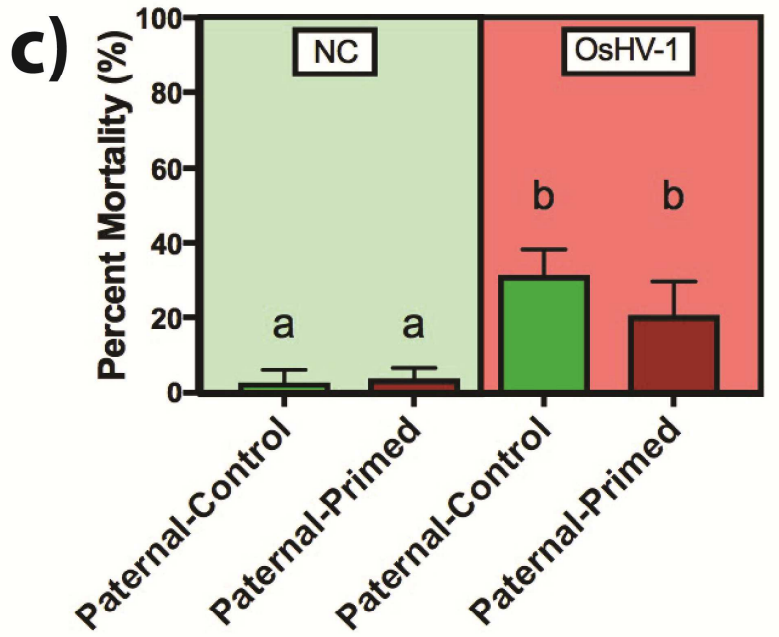

Paternal Effects

Figure 2: Schematic diagram of experimental design for investigating the contribution of

641 maternal and paternal immune stimulation to offspring performance. D-larvae from each

642 family were inoculated with OsHV-1 or control homogenate (NC). Cumulative mortality for

643 each treatment was determined at 48 hours post-inoculation (mean \pm standard deviation).

644 Different letters indicate significant differences $(p<0.05)$ between treatments. 

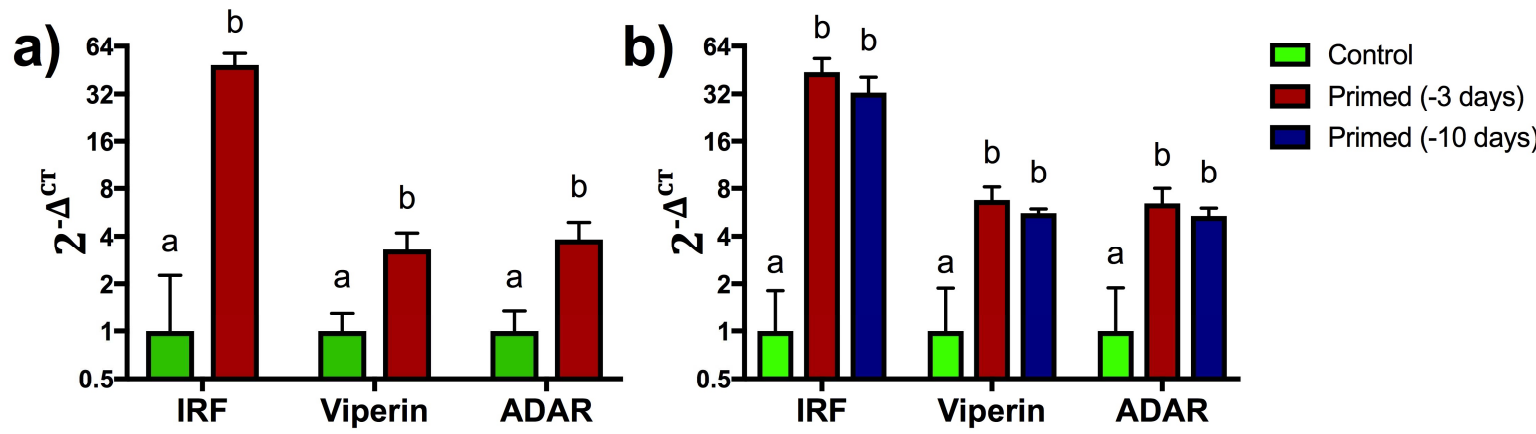

647 Figure 3: The expression of interferon regulatory factor (IRF), viperin and double-stranded

648 RNA-specific adenosine deaminase (ADAR) in unfertilized eggs of Crassostrea gigas that

649 were stimulated with poly(I:C) or seawater (control). a) experiment i: effect of time between

650 parental immune stimulation and spawning on offspring immunity to OsHV-1. b) experiment

651 ii: maternal effect on offspring immunity to OsHV-1. Expression is presented as the mean \pm

652 standard deviation. Different letters indicate significant differences $(p<0.05)$ between

653 treatments.

654 
a)

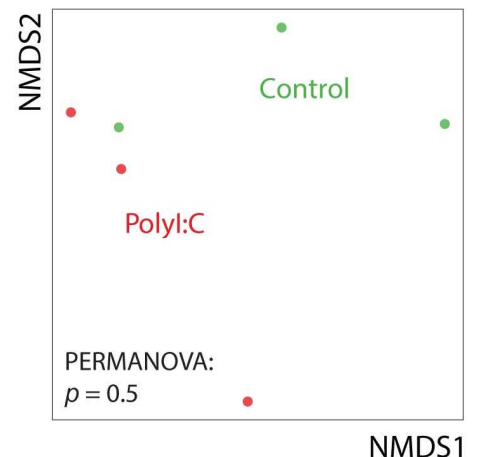

NMDS1

655

656 Figure 4: Transcriptional response of unchallenged D-larvae of C. gigas produced from

657 parents stimulated with poly(I:C) or seawater (control) prior to spawning. (a) Non-metric

658 multidimensional scaling (NMDS) plot summarizing the expression level of 14,479 gene

659 clusters identified by Trinity and Corset in pooled D-larvae samples produced from pair-

660 mated families. (b) Heat map of gene identified to be differentially expressed by RNA-seq

661 between unchallenged D-larvae.

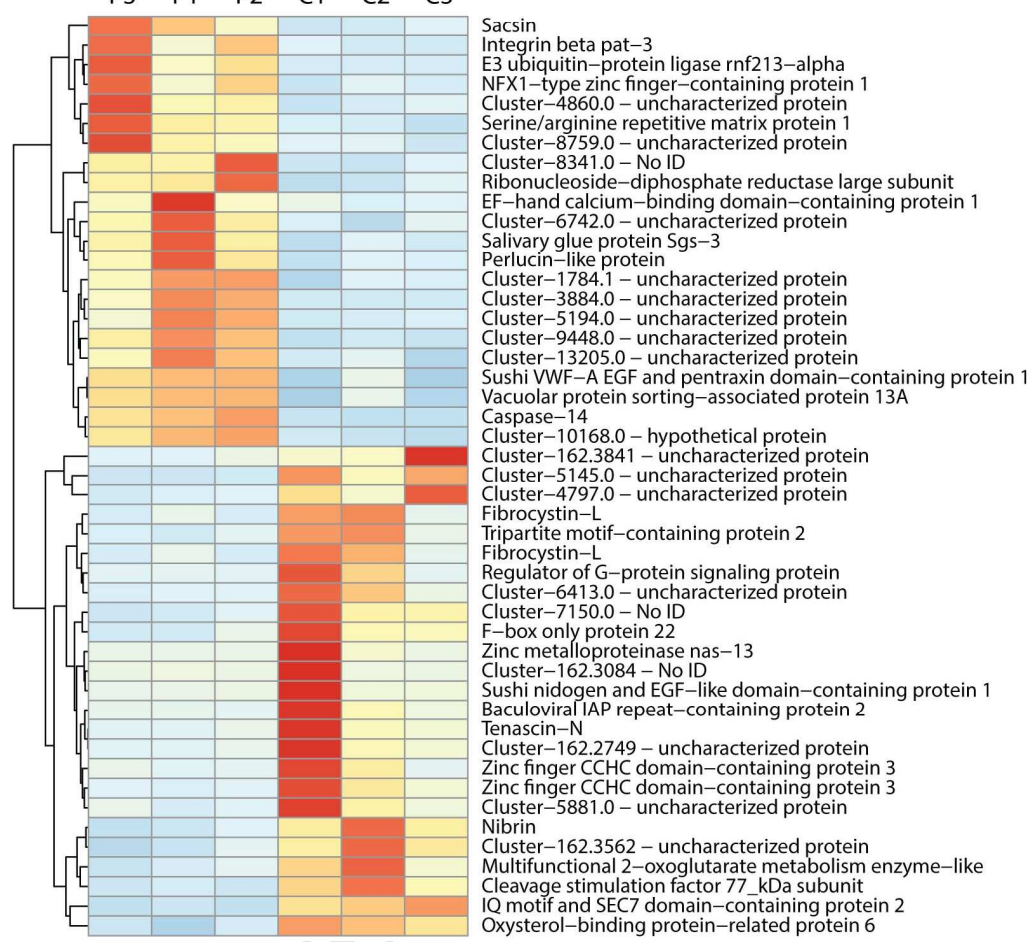

b)

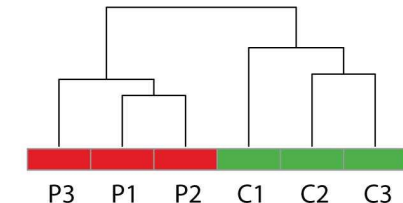

Treatment

Row Z-score

Polyl:C

$\begin{array}{lllll}-2 & -1 & 0 & 1 & 2\end{array}$ 
- The molecular mechanism involved in transgenerational immune priming was investigated in the oyster, Crassostrea gigas.

- Crassostrea gigas larvae have higher survival to OsHV-1 when their mothers, but not their fathers, are exposed to poly(I:C) prior to spawning.

- RNA-seq provided no evidence to suggest that parental exposure to poly(I:C) reconfigures antiviral gene expression in unchallenged larvae.

- Improved survival of $C$. gigas larvae might occur via maternal provisioning of antiviral compounds in the eggs. 